been affiliated to the International Council for Philosophy and Humanistic Studies of U.N.E.S.C.O. A permanent International Centre of Onomastics has been established at the Instituut voor Naamkund, of the University of Louvain. The Centre proposes to publish a bulletin Onoma, the first volume of which appeared in February 195 I and contained a report on the last congress, communications relating to the progress of onomastics in the 26 affiliated countries, and the first series of onomastic bibliographies.

\title{
Plan of Education in the Protestant Missions in Angola
}

ThE plan includes a basic scheme of village, regional, and area schools. Village schools operate during the dry season for about four months. The curriculum includes prerudimentary teaching of Portuguese as well as simple manual work.

Regional boarding schools serve a group of three to six villages, are organized by an African committee of Church members, and staffed by certified teachers. The curriculum includes, besides the official $\mathrm{I} a$ and $2 a$ Classe syllabus, agriculture, sewing, basketry, pottery, \&c., the course taking three to four years. Selected pupils from regional schools go on to a general school situated in the head village of each Pastoral area. These schools operate in the wet season, and in them pupils begin 3 Classe work of the official curriculum.

After one or two years at the area school pupils may be sent to boarding schools at mission stations, where they are prepared for the government examinations or are drafted to trade schools, or training schools for leaders. There are three training (Normal) schools, at Dondi, Quessua, and Quibocolo, where a four years' course includes study of Portuguese and specialized training for leadership: theoretical and practical teacher training, scientific agriculture, trade training, hygiene, home-making, \&c. In addition to this system of graded schools, vocational classes for young men and women who did not attend school in childhood, as well as adult literacy instruction, are organized by the Missions.

\section{East African Institute of Social Research}

THE first conference of fellows and associates of the East African Institute of Social Research took place at Makerere College, Kampala, the headquarters of the Institute, from 17 December to 23 December I950.

Papers were read on 'Field methods and field situations' in which individual field workers described briefly the characteristics of their areas, the object of their research, and the methods they felt to be appropriate for such a study. Professor Hoyt and Mr. Philip Powesland contributed papers from an economic point of view. A preliminary discussion followed on a scheme for the comparative study of African political systems in present-day East Africa. It is proposed to hold such conferences twice yearly. 